\title{
Ethnographic Study of the Umma Kalada Values of the Indigenous People of Loura and Its Application in Elementary Social Studies Learning
}

\author{
Heronimus Delu Pingge ${ }^{1 *}$, Nana Supriatna ${ }^{2}$, Sapriya $^{3}$, Abdul Azis Wahap ${ }^{4}$, \\ Rahel Maga Haingu ${ }^{5}$
}

\author{
1,2,3,4 Universitas Pendidikan Indonesia, Bandung \\ ${ }^{5}$ STKIP Weetebula \\ *Corresponding author. Email: pinggeroni@gmail.com
}

\begin{abstract}
Education and culture are two inseparable aspects. Education uses the student's culture or environment as a learning resource. Education too prepare students to work or live in a community environment. The research was carried out aimed at; 1) knowing the form of local wisdom and the values it containsin the umma kalada of the Loura indigenous people; 2) Utilization of value umma kalada community in elementary social studies learning for the formation of social skills. Research design is a qualitative research with ethnographic research methods. It was found that the form and value of the umma kalada local wisdom were found in the philosophy and function of the umma kalada, the shape of the house, and the patterns of interaction in the house and village. The values contained in the form of living together, unity, openness to the outside world, understanding of rights and obligations, religion, cooperation, a place for conflict resolution. These values can be integrated in elementary social studies learning for the formation of students' social skills by first assessing the subject matter and the form of social skills to be formed.
\end{abstract}

Keywords: Values Umma Kalada, Social Studies, Social Skills.

\section{INTRODUCTION}

Humans and culture are two inseparable elements. Humans as cultural heirs and also as cultural creators [1] School is an ideal means of passing on culture. Then the concept of culture-based learning emerged.In socio-cultural based learning, socio-cultural phenomena become a medium for students to transform their observations into creative forms and principles about nature and the environment [2] The implication is learning based on socio-cultural values, not only as a transmission process, but also to build critical thinking skills and act in students. Learning can create meaning and students gain an understanding of the information obtained as a rational foundation in addressing a cultural value they learn.
Learning which elevates local culture as a learning resource known as ethnopedagogy. The ethnopedagogical approach is one way of teaching and passing on the culture to students with utilize local wisdom as a learning resource.The educational values contained in local wisdom can regulate behaviors, ways of thinking, and communication that are beneficial to many people.[3]. Local wisdom is taught with the aim of equipping students with attitudes, knowledge, and spirituality in their area. Another goal is to preserve and develop regional excellence and wisdom that is useful for oneself and the environment in order to support national development.

Learning with the ethnopedagogical method is very important to be applied considering that Indonesia is a pluralistic country consisting of various ethnic groups and ethnicities which of course have different cultures [4].Globalization and 
technological developments can lead to cultural changes in Indonesian society. If ethnopedagogyoriented learning is not applied from an early age, then in the future globalization and rapid technological developments can shift local wisdom in society. This shift occurred because there was no clear boundary between local culture and foreign culture. This condition clearly shows that education in Indonesia needs to apply learning that is oriented towards local wisdom.

The role of the teacher in designing learning that comes from local culture very important. The 2013 curriculum explains that learning tools provided by the government provide opportunities for teachers in this area to be developed according to the situation of the student learning environment so that it is more contextual and uses local wisdom.[5]. local wisdom has a role as a means of cultural inheritance by certain communities and in certain places from generation to generation and is able to cope with rapid global developments [6].

At this time every individual also needs to have a number of competencies that must be possessed. Broadly speaking there are four skills that must be mastered in the second century according to Griffin, et al [7] The first relates to individual thinking activities, Second relates to individual work, third tools used in work, Fourth relates to living together in the global era. Meanwhile, Trilling and Fadel [8] explain three competencies in the 21st century, namely the first ability to learn and innovate, second the ability to manage information, technology tools and media and third the ability to work and live together. The $21 \mathrm{st}$ century competence is needed based on the findings that school graduates still lack competence in the areas of a) oral and written communication; b) think critically and solve problems, c) work ethics and professionalism, d) work in teams and collaborate, e) work in different groups, f) use technology, g) project management and leadership [7].

Referring to a number of competencies above, it can be seen that individuals are required to establish relationships with other people both in the world of work and in communication media. Social skills are the key word.Schools, in this case education, need to prepare students to have competent social skills. Goleman [9] positioning social skills as an intelligence that is owned by humans, namely emotional intelligence. In emotional intelligence, individuals manage their abilities in the form of emotional self-awareness, managing emotions. Make productive use of emotions, empathy, and build relationships.

This social intelligence can take the following forms: 1) Self-awareness: This ability relates to the understanding of feelings, thoughts and actions. Self- confidence and the ability to recognize one's own strengths and weaknesses. 2) Self-management: is a person's ability to manage emotions, thoughts and actions. Self-management is also related to the ability to manage stress, set life goals, and motivate yourself. 3) Social awareness: is the ability to understand other socio-culturally diverse people. 4) Relational Skills: is the ability and cultivation of relationships with others. This relates to clear speaking, active listening, cooperation and combating inappropriate actions, conflict resolution, 5) Responsible decision-making: regarding decisions, taking action in accordance with applicable norms and rules [10].

Schools have an important role in teaching knowledge and a number of skills to students. Primary schools as early educational institutions occupy an important position. A number of subjects such as natural sciences, mathematics, civics education and social science education must be able to teach social skills to students. If you look deeper, social studies is a subject that can facilitate the development of students in knowledge and skills. This is because the content of cocial studies talks about nationalism, culture, and a number of life skills.

Indonesia is currently implementing the "2013 curriculum". One of the characteristics of the 2013 curriculum is that "schools are an inseparable part of society that provides a planned learning experience, students apply the material being studied to the community and utilize the community as a learning resource"[5]. The characteristics of the curriculum are understood that the teaching and learning process in schools makes the surrounding community a source of learning. One of the learning resources available in the community is local wisdom [11].

The characteristics of the 2013 curriculum as an entry point for teaching culture-based learning using an ethnopedagogical approach. Indonesian culture is very diverse. One of the elements of Indonesian culture is the traditional house. Each province has its own uniqueness. One of them is the traditional house of the Loura traditional community on Sumba Island, East Nusa Tenggara.

The traditional house of the Loura traditional community is located in the wanno kalada (large village) and is known as the umma kalada. Umma kalada as a symbol and identity for the people. Apart from being a symbol of the Umma Kalada, it is also rich in values that can be used as a guide for life. Umma Kalada as a gathering place for clans or tribes in the Loura indigenous people.

Values in Umma Kalada can be used as strategies to teach social skills to elementary school students in the area of Loura and Sumba in general. Teaching social skills to elementary school students 
in the Loura region because this area is the entrance and exit point in Sumba. There are Tambolaka Airport and Waikelo Harbor[12]. Loura and Sumba are generally tourist destinations after Bali in the Central and Eastern Indonesia Region [13]. The majority of sellers of textiles or clothing and other economic goods are dominated by people outside Sumba and choose to stay.

The number of foreigners or outsiders who come in and out of Sumba and even settle in the Loura area is a problem in itself. For example, there is often bullying or extortion at tourist attractions [14, 15] on the other hand, the land belonging to the local community has been sold or has become the property of non-Sumba people. Meanwhile, the majority of the people of Sumba depend on farming and livestock[16]. It will be tbecomes a cultural intersection and is a trigger for conflict in the future, therefore students need to be equipped with social skills to be able to live side by side in diversity.

Values which is full of meaning contained in Umma Kalada into a cultural heritage that is rich in cultural values needs to be explored and implemented in the classroom. This needs to be done so that students who are in the Loura region are not uprooted from culture but are still open to changes.

Based on a number of concepts and problems above, this paper is a preliminary study of research that will answer the objectives of; 1) knowing the form of local wisdom and the values it contains in the umma kalada of the Loura indigenous people; 2)Utilization of value umma kalada community in elementary social studies learning for the formation of social skills.

\section{METHOD}

Research design used is a qualitative research with ethnographic methods. Qualitative research is a process of investigating understanding based on deep traditions about social or human problems [17]. The researcher builds a holistic picture, analyzes words, describes a detailed view of the information and conducts research in a natural environment. Participants in this ethnographic research are indigenous peoples living in the wanno kalada area of Loura who still maintain the umma kalada. The technique of collecting data is done by observing, interviewing, documenting. Meanwhile, for data analysis withwork procedure components of an interactive data analysis model from Miles dsn Huberman[18].

\section{RESULTS AND DISCUSSION}

The indigenous people of Loura are people who live geographically in the area of Loura District and Tambolaka City District, Southwest Sumba Regency. There are still many people who believe inbelief system in the ancestors who are familiar with "Marapu". Marapu is wealth in itself in terms of genuine belief in the Creator and Creator.

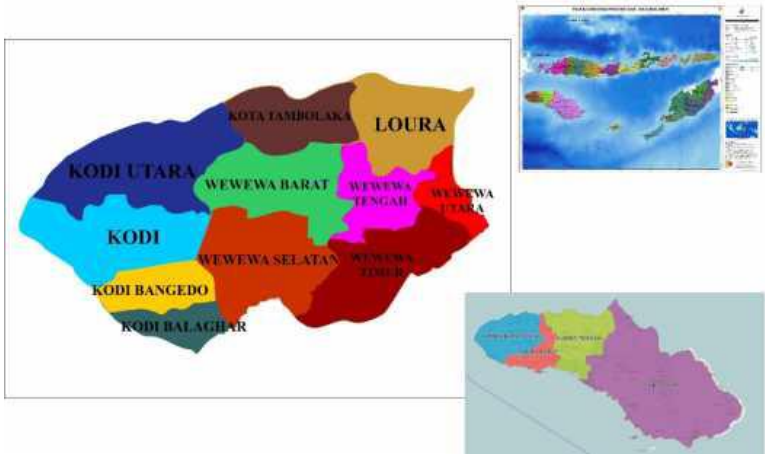

Figure.1. Research Location Map (Source: sumbabaratdayakab.bps.go.id)

Sumba with traditional house culture that having a distinctive shape with a different shape from traditional houses in other areas, traditional houses have high towers which are characteristic of them. Vertically the umma kalada is divided intothree parts, namely the lower part of the house, the middle of the house and the top of the house. In the view of the people of Sumba, the three parts seem to be symbols of nature that have meaning, namely the lower realm (the place of spirits), the middle realm (the place of humans) and the upper realm (the place of the gods). Horizontally based on function and gender. The left and right parts are separated into men's and women's areas, while the front and back are the areas for receiving guests, a bed or a place for "Mata Marapu".
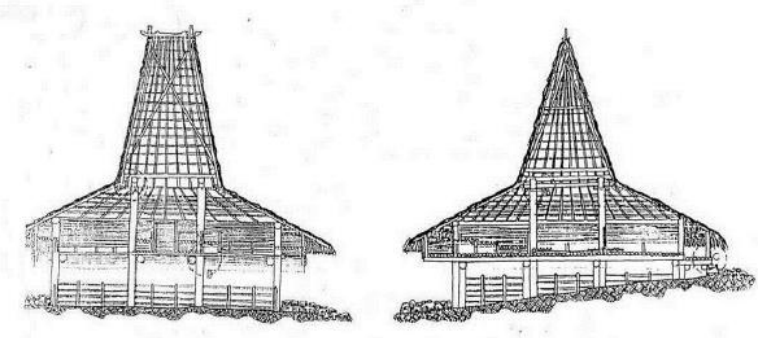

Figure 2. Pieces of Sumba Traditional Houses (Source:Widya Mandira University Research Team, 1992 ) 
Each tribe or Kabizzu has a traditional house. The traditional house is named with umma kalada. To distinguish the Umma Kalada, each tribe is given the name of the tribe at the end of the mention of the Umma Kalada. For example, "umma kalada Bukamangi, umma kalada Lamunde", which means traditional houses belonging to the Bukamangi and Lamunde tribes. umma kalada literally means big house. It is called a big house because the function of the umma kalada is a gathering place for all family members from within one tribe. Umma kalada as a symbol of the identity of the indigenous people of Loura, a symbol of unity. Umma Kalada also functions as a place to resolve conflicts, both internal conflicts within the Kabizzu and between Kabizzus.

In general, traditional Sumba houses are always built on hills surrounded by neatly arranged stone fences, and enclosed with two gates, as the exit and entrance. The purpose of building a village of Sumbanese people on the hill is for security. The situation of war between tribes at that time was an anticipation of the security and safety of members of the tribe and the tribe it self.

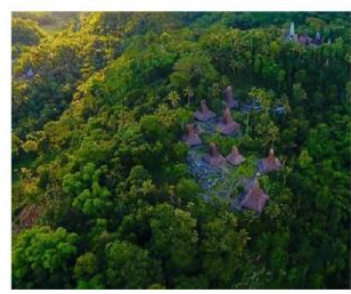

Figure 3. Traditional house pattern (Source: Gunawan Y, et al. 2018).

The Loura customary community is intertwined forge a strong togetherness between different Kabizzu or tribes in one wanno kalada.A strong form of togetherness in one wanno kalada with natara or a kind of public space that can be used together in receiving guests, performing traditional rituals and so on. There is also a design for each umma kalada with a fairly large katonga kalada or bale. Katonga kalada functions as a space for receiving guests, a traditional meeting place.

Utilization of the court in general in the wanno kalada as well as the katonga kalada which serves to receive guests or neighbors, this is a symbol that the indigenous people of Sumba are open to the existence of other people. Besides that, umma kalada meaning as a place of life after death. Literally the body is buried in the courtyard of the village, but the soul or spirit is believed to be dighabitation or be in an angle on umma kalada. Rato or customary head acts as an intermediary between spirits and living humans. The presence of a holy place in a traditional house indicates that indigenous people have adhered religious values.In religious life nhe religious values that will affect a person's social care [19].

Sumba adheres to a patrilineal kinship system that follows or ignores the father's offspring. Then setiap uma or the traditional house is usually inherited by the oldest son (birthright). Together with that inherited a number of inheritance, agricultural land, and ritual responsibilities. The inheritance is only used as use rights, while the ownership rights remain with the regency. kinship is closely related to the marriage system. Marriages will be carried out with a ritual of uniting the relationships between women and men but also uniting extended families or kabizzu. There was an exchange of goods of cultural value.The indigenous people of Louragenerally adheres to exogamous marriages, namely marriages conducted with partners outside the clan. In this way, men from one village would look for a partner in another village.

The values contained in the umma kalada customary community of Loura can be integrated in primary school social studies learning with the aim of forming students' social skills which include the formation of Self-awareness, Self-management, Social awareness, and Relationship skills. For example, its application is by designing "a learning model based on the Umma Kalada for forming students' social skills". The design of the learning model aims to support learning theories related to constructivism.

The steps of applying the Umma Kalada value in the formation of social skills of elementary school students in social studies learning are: first; examines the basic competencies (KD) of social studies subjects. It is intended whether the material is related to attitude formation, information or knowledge in nature, and or in the form of action; second; analyze the needs or cases experienced by students related to social skills issues. Third: choosing the values contained in the Umma Kalada according to the subject matter or the basic competencies taught based on the case or type of social skills being taught. Fourth: evaluate the implementation of learning with evaluation sheets or fortofolia.

\section{CONCLUSION}

Education cannot be separated from culture. Because culture is the source of learning that is closest to students. On the other hand, education is a means of inheriting culture. The effects of globalization affect all aspects of life. So the next generation must have a number of competencies, one of which is social skills.

Social skills as capital in building relationships that are without boundaries today. Therefore, since elementary school students need to be equipped with 
social skills. Social science subjects as a means of teaching these skills. The values in establishing social relationships taught to students must come from the student's cultural values. This is a form of making students not lose their identity or culture.

The values contained in the Umma Kalada of the Loura indigenous people contain values living together, unity, openness to the outside world, understanding of rights and obligations, religion, cooperation, a place for conflict resolution. These values can be integrated in elementary social studies learning for the formation of students' social skills by first assessing the subject matter and the form of social skills to be formed.

\section{ACKNOWLEDGMENTS}

Many thanks to the Indonesian University of Education (UPI) Bandung for teaching and training in conducting research and also to STKIP Weetebula for funding the research.

\section{REFERENCES}

[1] Mahdayeni, et al. Manusia Dan Kebudayaan (Manusia Dan Sejarah Kebudayaan, Manusia Dalam Keanekaragaman Budaya Dan Peradaban, Manusia Dan Sumber Penghidupan). TADBIR : Jurnal Manajemen Pendidikan Islam 7(2). 2019, pp 154-165

[2] Sarjio, Panen. Pembelajaran Berbasis Budaya: Model Inovatif Pembelajaran dan Implementasi Kurikulum Berbasis Kompetensi. Jurnal Pendidikan. 6(2), 2005. Pp 83-98

[3] Tilaar, H. A. R . Pedagogik Teoritis untuk Indonesia. Jakarta: PT Kompas Media Nusantara, 2015

[4] Oktavianti and Ratnasari.Etnopedagogi Dalam Pembelajaran Di Sekolah Dasar Melalui Media Berbasis Kearifan Lokal. Jurnal Refleksi Edukatika. 8 (2).,2018pp. 149-154

[5] Kemendikbud. Silabus Mata Pelajaran Sekolah Dasar/Madrasah Ibtidaiya (SD/MI) Mata Pelajaran Ilmu Pengetahuan Sosial (IPS), 2016

[6] Tinja, Y. Siti, M.T, and Hariyono. Pengembangan bahan ajar Tematik Berbasis Kearifan Lokal sebagai Upaya melestarikan budaya pada Siswa Sekolah dasar. jurnal Pendidikan: Teori, Penelitian, dan Pengembangan, 2(9),2017. pp.1257-1261
[7] Griffin, P., dkk. Assessment and Teaching of 21st Century Skills Springer Dordrecht Heidelberg London New York, 2012.

[8] Trilling and Fadel. 21st Century Skills: Learning for Life in Our Times. John Wiley \& Sons, 978-0-47-055362-6. 2009

[9] Goleman D. Emotional Intelegence (Kecerdasan Emosional) eds trj. Jakarta: PT Gramedia.2015

[10] CASEL. . Effective Social and Emotional Learning Programs Preschool and Elementary School. New York: Casel.2013

[11] Pingge, H.D.. Learning Materials Based On Local Wisdom Of Sumbanese As The Source Of Learning In Elementary School. Proceedings The 4th International Seminar on Social Studies and History Education. Universitas Pendidikan Indonesia. 2019

[12] sumbabaratdayakab.bps.go.id, 2016. Banyaknya Wisatawan Dalam Negeri dan Asing yang Menginap di Hotel menurut Bulan, $2013 \quad-\quad 2014 . \quad$ from https://sumbabaratdayakab.bps.go.id/statictabl e/2016/01/18/72/banyaknya-wisatawandalam-negeri-dan-asing-yang-menginap-dihotel-menurut-bulan-2013-2014-.html ，2016, accessed on 02 March 2020

[13] antaranews.com. Pulau Sumba unggulan baru pariwisata NTT. Nrom https://www.antaranews.com/berita/693848/pu lau-sumba-unggulan-baru-pariwisata-ntt. 2018 accessed on 02 March 2020,

[14] semarang.kompas.com, 2019. Wisatawan yang Berkunjung ke Sumba Barat Daya Dipalak Pemuda Mabuk dari https://semarang.kompas.com/read/2019/ 03/08/09362911/wisatawan-yang-berkunjungke-sumba-barat-daya-dipalak-pemudamabuk? page $=$ all, 2019. accessed on 02 March 2021

[15] Pos Kupang. LAGI, Rumah Ada di Sumba Barat Terbakar, Kali ini 22 Rumah Adat HabisDilalap, https://kupang.tribunnews.com/ 2020/08/10/lagi-rumah-ada-di-sumba-baratterbakar-kali-ini-22-rumah-adat-habis dilalap? page $=2.2020$ accessed on 02 March 2021 
[16] sumbabaratdayakab.bps.go.id. 2020 . Kabupaten Sumba Barat Daya Dalam Angka 2021.

https://sumbabaratdayakab.bps.go.id/publicati on/2021/02/26/a97f9c0fa3ea95fe3192aa84/ka bupaten-sumba-barat-daya-dalam-angka2021.html. accessed on 02 March 2021

[17] Creswell, J. W. Research Design: Qualitative, Quantitative, and Mixed Methods Approaches. (terj.) Yogyakarta: Pustaka Pelaja. 2010

[18] Miles, M.B. dan Huberman, A.M. Qualitative Data Analysis. London: Sage Publishers. 1989

[19] Bali, M.M dan Nurul F.. Internalisasi Karakter Religius Di Sekolah (Studi Kasus di SMP Nurul Jadid). Jurnal Mudarrisuna. 9(1). 2019 